\title{
Bilirubin Toxicity in a Neuroblastoma Cell Line N-115: II. Delayed Effects and Recovery
}

\author{
YAIR AMIT, MARK J. POZNANSKY, AND DAVID SCHIFF \\ Departments of Pediatrics [Y.A., D.S.] and Physiology [M.J.P.], University of Alberta, \\ Edmonton, Alberta, Canada T6G $2 R 7$
}

\begin{abstract}
Clinical studies have suggested that the early stages of bilirubin encephalopathy are reversible. These phenomena are investigated at the cellular level using the neuroblastoma cell line $\mathrm{N}-115$ as a model system. To determine whether the cell line $\mathrm{N}-115$ can recover from bilirubin toxicity, and whether the cellular function remains intact after a short period of bilirubin exposure during which time no toxic effects are manifest, the cells are exposed to bilirubin at varying concentrations and varying bilirubin:albumin ratios for 1 and $2 \mathrm{~h}$. The bilirubin is then washed out, and the cells are reincubated in fresh media with appropriate amounts of albumin. Mitochondrial function, $\left[{ }^{3} \mathrm{H}\right]$ thymidine uptake and $\mathrm{L}-\left[{ }^{35}\right.$ S]methionine uptake are assessed at 2,8 , and $24 \mathrm{~h}$ of reincubation after the bilirubin washout. After the short-term exposure, the cells begin to demonstrate evidence of toxicity in all parameters measured 8-24 h after the bilirubin washout. After the 2$h$ exposure to bilirubin, the cells demonstrate significant toxicity within $2 \mathrm{~h}$ of the bilirubin washout. The degree of toxicity seems to depend on the bilirubin:albumin ratio and bilirubin concentration. In general, after bilirubin exposure of $1 \mathrm{~h}$ or longer, the $\mathrm{N}-115$ cells develop evidence of toxicity which is progressive and irreversible. (Pediatr Res 25:369372,1989 )
\end{abstract}

\section{Abbreviations}

$\mathrm{B} / \mathrm{A}$, bilirubin to albumin molar ratio

HSA, human serum albumin

PFM, protein-free medium

MTT, 3-(4,5-dimethylthiazol-y-yl),-2,5-diphenyl tetrazolium bromide

Clinical studies have recently suggested that in the presence of hyperbilirubinemia the newborn infant will demonstrate abnormal evoked brain stem potentials, an indication of the early stages of bilirubin encephalopathy. Upon resolution of the hyperbilirubinemia, either spontaneously or after exchange transfusion, these abnormalities disappear. This suggests a reversibility to the early stages of bilirubin encephalopathy $(1-3)$. The role of albumin binding $(4,5)$, the integrity of the blood brain barrier (6), and the possible presence of a bilirubin oxidase enzyme (7) have been suggested as possible mechanisms in this phenomenon. Cowger (8) demonstrated that bilirubin toxicity in a tissue culture system was reversible with the addition of albumin. More recently, Hansen et al. (9) demonstrated a similar phenomenon

Received September 26, 1988; accepted November 18, 1988

Reprint requests to Dr. D. Schiff, Department of Pediatrics, 2C3 Walter Mackenzie Health Sciences Centre, University of Alberta, Edmonton, Alberta, Canada T6G 2R7.

Supported by the Medical Research Council of Canada, Grant MA 9184. Y.A. is a Clinical Fellow of the Alberta Heritage Foundation for Medical Research. in Hippocampal slices, and Wennberg (10) has shown a reversibility phenomenon in red blood cell and mitochondrial uptake of bilirubin.

Laboratory studies have demonstrated that bilirubin can affect a host of different cellular functions (11). Recent studies from our laboratory have shown that bilirubin toxicity in the neuroblastoma cell line N-115 was dependent on bilirubin concentration, $\mathrm{B} / \mathrm{A}$, and time of exposure (12). The effect on mitochondrial function, $\left[{ }^{3} \mathrm{H}\right]$ thymidine uptake and $\mathrm{L}-\left[{ }^{35} \mathrm{~S}\right]$ methionine uptake became manifest after $2 \mathrm{~h}$ of bilirubin exposure (12). As these vital cellular functions are affected by a short-term exposure to bilirubin, the N-115 cell line offers a good model system to study the early stages of bilirubin toxicity. The present study examines the reversibility of bilirubin toxicity in the early stages with respect to cellular function, as well as the possible delayed effects of a short-term exposure to three cellular functions, wherein no bilirubin toxicity was manifest. Contrary to the clinical situation, the present results indicate an irreversibility even in the early stages of bilirubin toxicity to the neural cell line.

\section{MATERIALS AND METHODS}

Chemicals. All reagents are analytical grade chemicals and include bilirubin (Lot 13F0846), HSA (fraction v, essentially FFA-free) and MTT purchased from Sigma Chemical Co., St. Louis, MO. Bilirubin purity was verified as previously described (12). Dulbecco's Modified Eagle Medium, Dulbecco's PBS, and FCS were obtained from Grand Island Biologicals, Canada. $\left[{ }^{3} \mathrm{H}\right]$ thymidine (sp act $15.1 \mathrm{Ci} / \mathrm{mmol}$ ) and $51-\left[{ }^{35} \mathrm{~S}\right]$ methionine (sp act $1129 \mathrm{Ci} / \mathrm{mmol}$ ) were purchased from DuPont, Mississauga, Ontario, Canada.

$\mathrm{N}-115$ cells. Cells of the murine neuroblastoma cell line $\mathrm{N}-115$ are seeded at a concentration of $5-8 \times 10^{5}$ cells/plate on $35-\mathrm{mm}$ culture dishes (Falcon Labware, Oxnard, CA) and grown in standard Dulbecco's Modified Eagle Medium plus $10 \%$ FCS, pH 7.4 , at $37^{\circ} \mathrm{C}$, in $5 \% \mathrm{CO}_{2}$ humidified atmosphere for $12 \mathrm{~h}$. The medium is then removed, the cells washed twice with sterile PBS and reincubated in $1 \mathrm{~mL}$ of PFM (12), plus HSA for another 12 $h$ before setting up the experiments with bilirubin. The HSA and bilirubin concentrations were varied in different experiments to meet the required final $\mathrm{B} / \mathrm{A}$.

Experimental conditions. All procedures involving bilirubin are carried out in a dimly lit room. Stock solutions of bilirubin in $0.1-\mathrm{N} \mathrm{NaOH}$ and HSA in PBS are prepared as described previously (12). Bilirubin is added to the culture medium to achieve the appropriate bilirubin concentration and B/A. An equimolar amount of $0.1-\mathrm{N} \mathrm{HCl}$ is added to restore the $\mathrm{pH}$ of the media to 7.4. Control cells are grown as above, and $0.1-\mathrm{N}$ $\mathrm{NaOH}$ and $0.1-\mathrm{N} \mathrm{HCl}$ are added to the media in the same vol as in the medium of the bilirubin-treated cells.

At the end of the exposure to bilirubin, the medium is gently removed, and the cells are washed twice with sterile PBS and reincubated in PFM plus HSA. Each of the studies outlined below were carried out in triplicate analyses. 
Toxicity is assessed at appropriate intervals as follows:

I) To assess cell viability and mitochondrial function, MTT is prepared and sterilized as described before (12). Aliquots of 100 $\mu \mathrm{L}$ are added to the medium and incubated for $60 \mathrm{~min}$. Then the cleaved dye is dissolved in $1 \mathrm{~mL}$ isopropanol- $\mathrm{HCl}(0.04 \mathrm{~N})$, by agitation with repeated pipetting, until a blue solution is obtained. The absorbance of the individual culture dish is then read in a diode array spectrophotometer (Hewlett-Packard Co., Palo Alto, CA) with a test wavelength of $570 \mathrm{~nm}$ and a reference wavelength of $630 \mathrm{~nm}$ (13). Only live cells will cleave the dye to give an increase in absorbance at $570 \mathrm{~nm}$. The difference in absorbances at 570 and $630 \mathrm{~nm}$ is a direct measure of mitochondrial function and cell viability.

2) $\left[{ }^{3} \mathrm{H}\right]$ thymidine and $\mathrm{L}-\left[^{35} \mathrm{~S}\right]$ methionine uptake: At $1 \mathrm{~h}$ before the end of the reincubation period, the cells are pulse labeled with either $\left[{ }^{3} \mathrm{H}\right]$ thymidine $(2 \mu \mathrm{Ci} /$ plate $)$ or $\mathrm{L}-\left[{ }^{35} \mathrm{~S}\right]$ methionine $(25$ $\mu \mathrm{Ci} /$ plate) for $60 \mathrm{~min}$. The medium is removed, the cells are washed twice with PBS, and dislodged from the plate and suspended in $0.5 \mathrm{~mL}$ PBS in an Eppendorf test tube. The cell suspension is then vortexed, and aliquots are taken for DNA (14) or protein (15) estimation and for measuring the radioactivity by liquid scintillation counting using ACS (Amersham Corp., Arlington Heights, IL) as scintillant. The radioactivity related to $\mathrm{L}-\left[{ }^{35} \mathrm{~S}\right] \mathrm{methionine}$ uptake was measured in the cellular protein fraction precipitated with $1 \mathrm{~mL} 10 \%$ trichloracetic acid.

To determine whether cells exposed to bilirubin, without evidence of toxicity, continue to function normally after a bilirubin washout and whether cells that already demonstrate bilirubin toxicity can recover their function once removed from bilirubin, the following experiments are carried out:

1) Cells are exposed to $100-\mu \mathrm{M}$ bilirubin, B/A 1.5 for $0.5,1$, 2,3 , and $4 \mathrm{~h}$. The cells are washed free of bilirubin and reincubated in fresh PFM containing 66- $-\mu \mathrm{M}$ HSA. Mitochondrial function (MTT assay), and $\left[{ }^{3} \mathrm{H}\right]$ thymidine uptake are then assessed at 2,8 , and $24 \mathrm{~h}$ after the bilirubin washout. $\mathrm{L}-\left[{ }^{35} \mathrm{~S}\right]$ methionine uptake (TCA precipitable) is assessed in a similar fashion, but only after 1 - and 2 -h bilirubin exposure.

2) To determine whether varying bilirubin concentration modifies the responses, cells are incubated with bilirubin concentrations of $25,50,75$, and $100 \mu \mathrm{M}, \mathrm{B} / \mathrm{A} 1.5$, for 1 and $2 \mathrm{~h}$. The cells are then washed free of bilirubin and reincubated in fresh PFM with appropriate concentrations of HSA. $\left[{ }^{3} \mathrm{H}\right]$ thymidine uptake is assessed at 2,8, and $24 \mathrm{~h}$ after the bilirubin washout.

3) To assess the role different B/A may have on these cells and their ability to recover from bilirubin toxicity, the following experiment is carried out. Cells are exposed to bilirubin concentrations ranging from 50 to $200 \mu \mathrm{M}$, with $100-\mu \mathrm{M}$ HSA, yielding $\mathrm{B} / \mathrm{A}$ of $0.5,1,1.5$, and 2 . After $2 \mathrm{~h}$ of exposure to bilirubin, the cells are washed free of bilirubin and reincubated in fresh PFM containing $100-\mu \mathrm{M}$ HSA. $\left[{ }^{3} \mathrm{H}\right]$ thymidine uptake, L- $\left[{ }^{35} \mathrm{~S}\right]$ methionine uptake, and MTT assay are carried out at 2 and $24 \mathrm{~h}$ after the bilirubin washout.

\section{RESULTS}

The effect of bilirubin ( $100 \mu \mathrm{M}, \mathrm{B} / \mathrm{A} 1.5)$ exposure for different durations on $\left[{ }^{3} \mathrm{H}\right]$ thymidine uptake and mitochondrial function

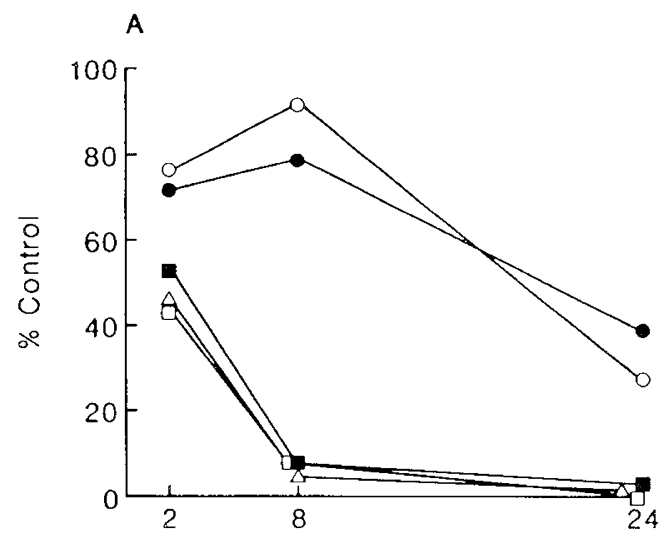

B

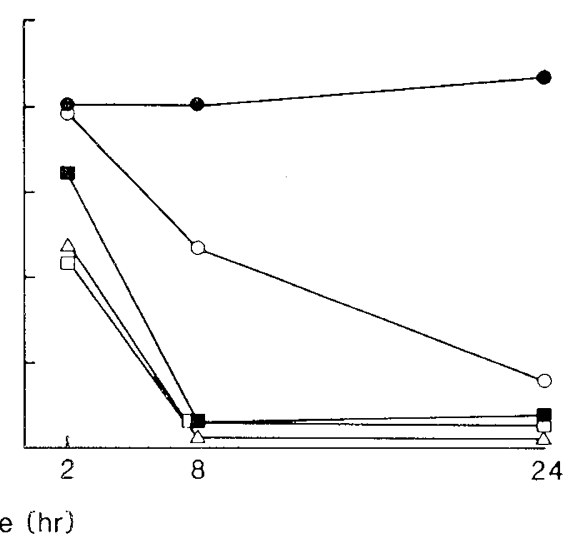

Fig. 1. The effect of reincubation of cells in fresh bilirubin-free medium (after bilirubin removal) on the MTT assay $(A)$ and $\left[{ }^{3} \mathrm{H}\right]$ thymidine uptake (B) of N-115 cells initially exposed to $100-\mu \mathrm{M}$ bilirubin, B/A 1.5 for $0.5 \mathrm{~h}(\bullet) ; 1 \mathrm{~h}(\mathrm{O}) ; 2 \mathrm{~h}(\mathbf{\square}) ; 3 \mathrm{~h}(\mathbb{Z})$; and $4 \mathrm{~h}(\triangle)$.

Table 1. Effect of bilirubin exposure time $(0.5,1,2,3$, and $4 h)$ on cell viability and mitochondrial function and recovery potential 2,8 , and $24 \mathrm{~h}$ after the cells are washed free of bilirubin; samples assayed in triplicate

\begin{tabular}{|c|c|c|c|c|c|c|c|c|c|c|c|c|}
\hline & \multicolumn{2}{|c|}{ Control } & \multicolumn{2}{|c|}{$0.5 \mathrm{~h}$} & \multicolumn{2}{|c|}{$1 \mathrm{~h}$} & \multicolumn{2}{|c|}{$2 \mathrm{~h}$} & \multicolumn{2}{|c|}{$3 \mathrm{~h}$} & \multicolumn{2}{|c|}{$4 \mathrm{~h}$} \\
\hline & DNA* & MTT' & DNA & MTT & DNA & MTT & DNA & MTT & DNA & MTT & DNA & MTA \\
\hline 2-h reincubation & $\begin{array}{r}15.63 \\
\pm 0.06 \\
9.48 \\
\pm 0.81\end{array}$ & $\begin{array}{r}0.1735 \\
\pm 0.0082 \\
0.1090 \\
\pm 0.0103\end{array}$ & $\begin{array}{r}14.55 \\
\pm 0.34\end{array}$ & $\begin{array}{r}0.1261 \\
\pm 0.0072\end{array}$ & $\begin{array}{r}13.99 \\
\pm 0.30\end{array}$ & $\begin{array}{r}0.1331 \\
\pm 0.0071\end{array}$ & $\begin{array}{r}9.34 \\
\pm 1.12\end{array}$ & $\begin{array}{r}0.0535 \\
\pm 0.0044\end{array}$ & $\begin{array}{r}9.21 \\
\pm 0.76\end{array}$ & $\begin{array}{r}0.0468 \\
\pm 0.0082\end{array}$ & $\begin{array}{r}8.28 \\
\pm 1.35\end{array}$ & $\begin{array}{r}0.0509 \\
\pm 0.0027\end{array}$ \\
\hline 8-h reincubation & $\begin{array}{r}14.03 \\
\pm 2.06 \\
18.81 \\
\pm 0.34\end{array}$ & $\begin{array}{r}0.2185 \\
\pm 0.0091 \\
0.1382 \\
\pm 0.0143\end{array}$ & $\begin{array}{r}15.50 \\
\pm 1.64\end{array}$ & $\begin{array}{r}0.1734 \\
\pm 0.0351\end{array}$ & $\begin{array}{r}12.75 \\
\pm 0.43\end{array}$ & $\begin{array}{r}0.1989 \\
\pm 0.0094\end{array}$ & $\begin{array}{r}18.23 \\
\pm 2.51\end{array}$ & $\begin{array}{r}0.0342 \\
\pm 0.0059\end{array}$ & $\begin{array}{r}15.66 \\
\pm 3.56\end{array}$ & $\begin{array}{r}0.0338 \\
\pm 0.0096\end{array}$ & $\begin{array}{r}17.53 \\
\pm 2.27\end{array}$ & $\begin{array}{r}0.0102 \\
\pm 0.0021\end{array}$ \\
\hline 24-h reincubation & $\begin{array}{l}22.99 \\
\pm 1.93 \\
22.17 \\
\pm 0.81\end{array}$ & $\begin{array}{r}0.1567 \\
\pm 0.0006 \\
0.0863 \\
\pm 0.0145\end{array}$ & $\begin{array}{l}22.32 \\
\pm 2.96\end{array}$ & $\begin{array}{r}0.0618 \\
\pm 0.0114\end{array}$ & $\begin{array}{r}19.77 \\
\pm 2.88\end{array}$ & $\begin{array}{r}0.0422 \\
\pm 0.0117\end{array}$ & $\begin{array}{r}19.79 \\
\pm 1.82\end{array}$ & $\begin{array}{r}0.0035 \\
\pm 0.0061\end{array}$ & $\begin{array}{r}19.17 \\
\pm 1.82\end{array}$ & $\begin{array}{r}0.0011 \\
\pm 0.0019\end{array}$ & $\begin{array}{r}17.27 \\
\pm 1.05\end{array}$ & $\begin{array}{r}0.0017 \\
\pm 0.0030\end{array}$ \\
\hline
\end{tabular}

\footnotetext{
* Expressed as $\mu \mathrm{g} /$ plate.

+ Expressed as $\triangle \mathrm{ABS}(570-630) \mathrm{nm}$.
} 
are given in Figure 1 and Table 1. Cells exposed to bilirubin for 0.5 and $1 \mathrm{~h}$ show no effects on $\left[{ }^{3} \mathrm{H}\right]$ thymidine uptake and MTT assay. The cells appear to be functioning normally $8 \mathrm{~h}$ after the bilirubin washout. However, at $24 \mathrm{~h}$ there is a significant reduction in these cellular functions. In cells exposed to bilirubin for $2 \mathrm{~h}$ or longer, significant reduction in these functions are seen at $2 \mathrm{~h}$ after the bilirubin washout, and this effect is progressive with time. At $24 \mathrm{~h}$, the cell viability is well below $20 \%$. Similar results are obtained when toxicity is assessed by $\mathrm{L}-\left[{ }^{35} \mathrm{~S}\right]$ methionine uptake as seen in Figure 2.

The effect of varying bilirubin concentration on $\left[{ }^{3} \mathrm{H}\right]$ thymidine uptake is demonstrated in Figure 3. After exposure to bilirubin of $25,50,75$, and $100 \mu \mathrm{M}, \mathrm{B} / \mathrm{A} 1.5$, the cells do not demonstrate any toxic effect for the first $8 \mathrm{~h}$ after the bilirubin washout. After $24 \mathrm{~h}$, there is a significant decrease in $\left[{ }^{3} \mathrm{H}\right]$ thymidine uptake, which is more pronounced at $100 \mu \mathrm{M}$ bilirubin; $70 \%$ compared to $25 \%$ at $25-\mu \mathrm{M}$ bilirubin. After a $2-\mathrm{h}$ exposure to bilirubin, the suppression of $\left[{ }^{3} \mathrm{H}\right]$ thymidine uptake becomes apparent at $2 \mathrm{~h}$ after the bilirubin washout at concentrations above $50-\mu \mathrm{M}$ bilirubin. At $8 \mathrm{~h}$ and $24 \mathrm{~h},\left[{ }^{3} \mathrm{H}\right]$ thymidine uptake is reduced at all concentrations of bilirubin, and this is more pronounced at the higher bilirubin concentrations (Fig. 3).

The effect of varying $\mathrm{B} / \mathrm{A}$ on bilirubin toxicity and the inability of the cells to regain normal function after this exposure is demonstrated in Figure 4. After a 4-h exposure of the cells to medium containing constant HSA and variable bilirubin concentrations, the 2 -h postbilirubin washout period is associated with mitochondrial dysfunction after incubating the cells with solu-

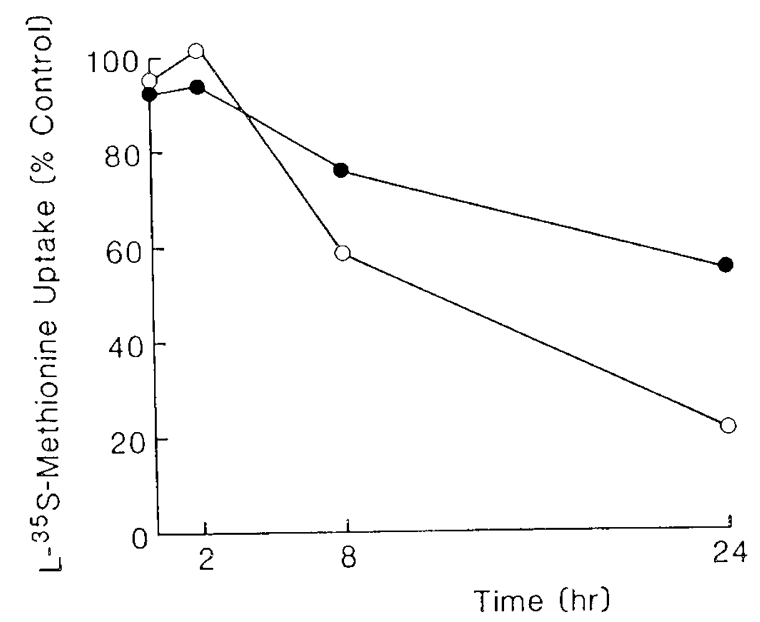

Fig. 2. The effect of reincubation of cells in fresh bilirubin-free medium (after bilirubin removal) on $\mathrm{L}-\left[{ }^{35} \mathrm{~S}\right]$ methionine uptake by $\mathrm{N}-115$ cells initially exposed to $100-\mu \mathrm{M}$ bilirubin, B/A 1.5 for $1 \mathrm{~h}(\bullet)$ and $2 \mathrm{~h}$ (O). tions of $\mathrm{B} / \mathrm{A}$ greater than 1 . No signs of toxicity are evident at $\mathrm{B} / \mathrm{A}$ 0.5. A similar effect is also seen with $\left[{ }^{3} \mathrm{H}\right]$ thymidine and $\mathrm{L}$ ${ }^{35}$ S ] methionine uptakes at B/A greater than one. After $24 \mathrm{~h}$ the damaged cells demonstrate a continuing reduction in all cell functions tested with no signs of recovery. These effects are more pronounced at the higher $\mathrm{B} / \mathrm{A}$.

\section{DISCUSSION}

It is well established that bilirubin is toxic to neural cells; however, the mechanism and pathogenesis of its toxicity remains unclear $(6,8)$. As preventive measures are taken very early during the course of neonatal hyperbilirubinemia, the number of cases with irreversible bilirubin encephalopathy are now of rare occurrence. However, clinical studies using auditory brainstem evoked responses in hyperbilirubinemic neonates have shown reversibility of the acute toxic effects of bilirubin. Once the hyperbilirubinemia has subsided, the abnormal responses were seen to normalize $(1-3)$. A similar phenomenon has been suggested in laboratory studies on different cell systems $(8-10,16)$.

The removal of tissue-bound bilirubin is thought to be a process comprising either changes in $\mathrm{B} / \mathrm{A}$, enzymatic oxidation of bilirubin, or clearance of bilirubin from otherwise undamaged brain tissue to the blood. By virtue of the albumin's affinity for bilirubin, the use of an albumin infusion during hyperbilirubinemia and/or exchange transfusion has been proposed as a means of protecting the infant's brain from the pigment and/or indeed removing the bilirubin from brain tissue $(4,17,18)$. Brodersen (7) has suggested the possibility of bilirubin oxidase enzymes within the neural cell, which might play a role in protecting the cell by oxidizing the unbound pigment. Bilirubin is capable of free diffusion across the lipid bilayer (19) and can effectively cross the cell membrane and move back into the circulation (6).

What makes some bilirubin toxic effects reversible and others irreversible is unclear. Although the auditory brainstem evoked responses still needs further refinement before a definitive conclusion can be made (20), in most of the laboratory studies, the toxic effects have been observed under bilirubin concentrations and B/A not usually encountered in the clinical situation (17).

In the studies reported here, where stable bilirubin solutions were used (21), it was possible to demonstrate that bilirubin is indeed toxic to various cellular functions. Once toxicity ap. peared, this was irreversible, despite reincubation of the cells with fresh medium and HSA in the absence of bilirubin. Moreover, after a short term exposure of 60 min, during which toxicity was not manifest, bilirubin-induced toxicity appeared later on. This can be used as an argument against the presence of a bilirubin oxidase enzyme system in the $\mathrm{N}-115$ cell line. The presence of this enzyme in neural cells is speculative and to date has not been characterized. The fact that in this study the cells

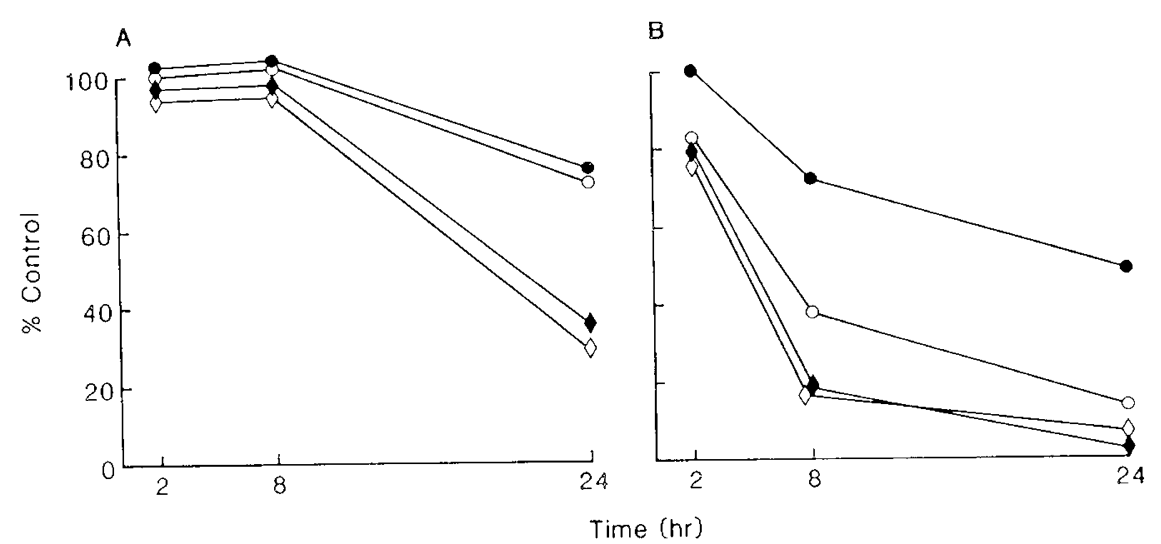

Fig. 3. The effect of reincubation of cells in fresh bilirubin-free medium on $\left[{ }^{3} \mathrm{H}\right]$ thymidine uptake. Cells were exposed to $25-\mu \mathrm{M}$ bilirubin $(-)$ $50-\mu \mathrm{M}$ bilirubin $(\bigcirc), 75-\mu \mathrm{M}$ bilirubin $(\bullet)$, and $100-\mu \mathrm{M}$ bilirubin $(\diamond), \mathrm{B} / \mathrm{A} 1.5$, for $1 \mathrm{~h}(A)$ and $2 \mathrm{~h}(B)$. 


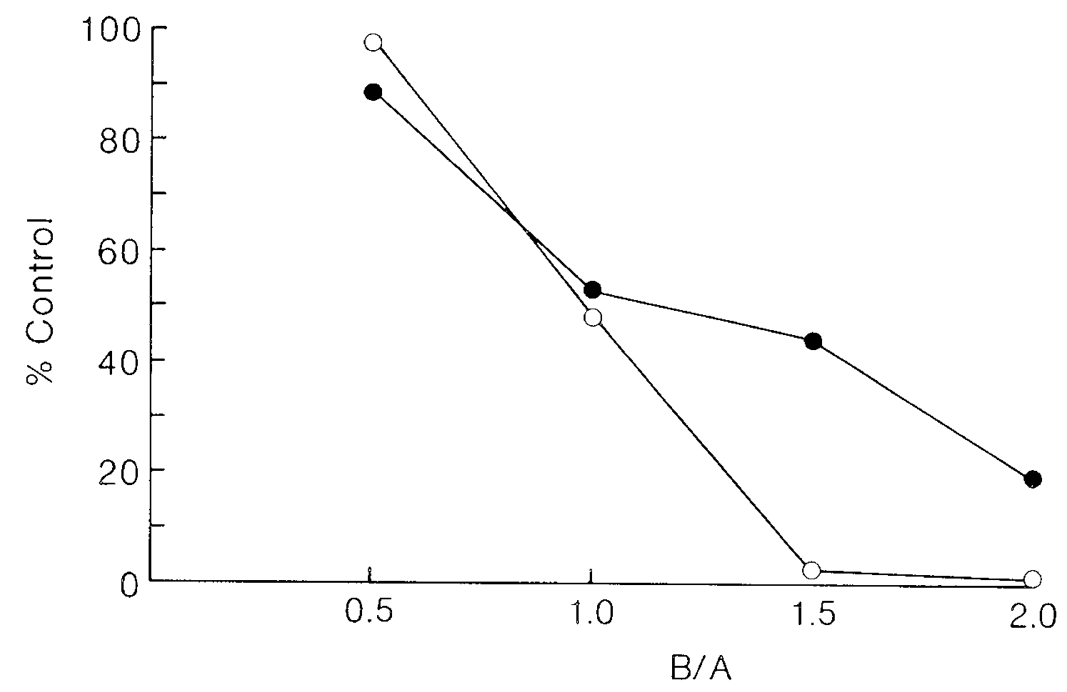

Fig. 4. The recovery effect of the bilirubin washout at $2 \mathrm{~h}(-)$ and $24 \mathrm{~h}(\mathrm{O})$ by $\mathrm{N}-115$ cells on mitochondrial function using the MTT assay after a 2-h exposure to bilirubin at concentrations ranging from $50 \mu \mathrm{M}$ to $200 \mu \mathrm{M}$ and a fixed HSA concentration of $100 \mu \mathrm{M}$, thus yielding B/A $0.5,1$, 1.5 , and 2 .

do not recover from bilirubin exposure and toxicity may be a reflection of the duration of the exposure and the higher $\mathrm{B} / \mathrm{A}$ used. In the study recently reported by Wennberg (10), the duration of bilirubin exposure was $15 \mathrm{~min}$ and $\mathrm{B} / \mathrm{A}$ did not exceed 1.3. Under these conditions, he was able to remove bilirubin taken up by the red blood cell. The red blood cell is a known bilirubin-carrying agent and is a useful model for assessing bilirubin transport and bilirubin binding to tissues; as such, it may not necessarily reflect the mechanisms for bilirubin toxicity in neural intracellular organelles. Nonetheless in both cell systems and in the clinical situation, the amount of free bilirubin available and the duration of exposure would appear to be among the critical factors leading to the irreversible stage of bilirubin toxicity. The amount of free bilirubin present in a system is dependent on the albumin concentration. The binding and buffering capacity of plasma albumin to bilirubin begins to break down rapidly as the $\mathrm{B} / \mathrm{A}$ approaches unity (22). Moreover, albumin binding is transitory and reversible with the bound and the free bilirubin molecules undergoing rapid exchange (23). These dynamic changes could account for the toxicity seen in cells exposed to solutions of $\mathrm{B} / \mathrm{A} \geq 1$ and for the permanent effect of bilirubin on purified proteins (16).

It is concluded that under appropriate conditions of bilirubin concentration, $\mathrm{B} / \mathrm{A}$, and time of exposure, the bilirubin toxicity in the $\mathrm{N}-115$ cell is a progressive and irreversible process. The critical safe time before the development of toxicity has not been defined for this cell line, and as yet not for the clinical situation. This has significant implications to our understanding of the pathogenesis of bilirubin encephalopathy, and subsequent clinical management of the hyperbilirubinemic infant and prevention of bilirubin encephalopathy.

Acknowledgment. The authors thank Deanna Moores and Shirley Fedunec for technical assistance, and Sigrid Barrow for secretarial assistance.

\section{REFERENCES}

1. Wennberg RP, Ahlfors CE, Bickers R, McMurtry CA, Shetter JL 1982 Abnor$\mathrm{mal}$ auditory brain stem responses in a newborn infant with hyperbilirubinemia: improvement with exchange transfusion. J Pediatr 100:624-626

2. Nakamura H, Takada S, Shimabuku R, Matsuo M, Matsuo T, Negishi H 1985
Auditory nerve and brain stem responses in newborn infants with hyperbilirubinemia. Pediatrics 75:703-708

3. Nwaesei CG, Van Aerde J, Boyden M, Perlman M 1984 Changes in auditory brainstem responses in hyperbilirubinemic infants before and after exchange transfusion. Pediatrics 74:800-803

4. Chan G, Schiff D 1976 Variance of albumin loading in exchange transfusion. J Pediatr 88:609-611

5. Ebbeson $F 1981$ Effect of exchange transfusion on serum reverse albumin for binding of bilirubin and index of serum bilirubin toxicity. Acta Paediatr Scand 70:643-647

6. Levine RL, Fredericks WR, Rapoport SI 1985 Clearance of bilirubin from rat brain after reversible osmotic opening of the blood brain barrier. Pediatr Res 19:1040-1043

7. Brodersen R, Bartels P 1969 Enzymatic oxidation of bilirubin. Eur J Biochem 10:468-473

8. Cowger ML 1971 Mechanism of bilirubin toxicity on tissue culture cells: factors that affect toxicity, reversibility by albumin, and comparison with other respiratory poisons and surfactants. Biochem Med 5:1-16

9. Hansen TWR, Bratlid D, Walaas SI 1988 Bilirubin decreases phosphorylation of synaptin $I$, a synaptic vesicle associated neuronal phosphoprotein in intact synaptosomes from rat cerebral cortex. Pediatr Res 23:219-223

10. Wennberg RP 1988 The importance of free bilirubin acid salt in bilirubin uptake by erythrocytes and mitochondria. Pediatr Res 23:443-447

11. Karp WB 1979 Biochemical alterations in neonatal hyperbilirubinemia and bilirubin encephalopathy: a review. Pediatrics 64:361-368

12. Schiff D, Chan G, Poznansky MJ 1985 Bilirubin toxicity in neural cell lines N-115 and NBR10A. Pediatr Res 19:908-911

13. Mosmann T 1983 Rapid colorimetic assay of cellular growth and survival application to proliferation and cytotoxicity assays. J Immunol Methods 65:55-63

14. Burton K 1956 A study of the conditions and mechanisms of diphenylamine reaction for the colorimetric estimation of DNA. Biochem $\mathrm{J}$ 62:315-323

15. Lowry OH, Rosebrough NJ, Farr AL, Randall RJ 1951 Protein measurement with the folin phenol reagent. J Biol Chem 193:265-275

16. Kimihiko S, Nakamura H, Matsuo T 1985 Mode of inhibitory action of bilirubin on protein kinase C. Pediatr Res 19:587-590

17. McDonagh AF 1979 Bile pigments: bilatriens and 5, 15-biladiens. In: Dolphin D (ed) The Porphyrins, Academic Press Inc New York, pp 380-384

18. Robinson PJ, Rapaport SI 1987 Binding effect of albumin on uptake of bilirubin by the brain. Pediatrics 79:553-558

19. Hayward D, Schiff D, Fedunec S, Chan G, Davis PJ, Poznansky MJ 1986 Bilirubin diffusion through lipid membranes. Biochim Biophys Acta 8600:149-153

20. Perlman M, Frank JW 1988 Bilirubin beyond the blood brain barrier. Pediatrics $81: 304-315$

21. Hayward D, Amit Y, Chan G, Fedunec S, Schiff D 1987 Solubility and stability of bilirubin in tissue culture incubates. Clin Res 25:234(abstr)

22. Johnson L, Garcia ML, Figueroa E, Sarmiento F 1961 Kernicterus in rats lacking glucuronyl transferase. Am J Dis Child 101:322-349

23. Brodersen R 1979 Bilirubin solubility and interaction with albumin and phospholipid. J Biol Chem 254:2364-2369 